\title{
Coordination Model in Hinterland Chain of Hub-and-Spoke Export Trade Logistics
}

\author{
Sita Aniisah Sholihah (ID, T.M.A. Ari Samadhi (ID), Andi Cakravastia (ID, Senator Nur Bahagia \\ Institut Teknologi Bandung (Indonesia) \\ avec_sita@yahoo.com,asamadhi@mail.ti.itb.ac.id,andi@mail.ti.itb.ac.id,senator@mail.ti.itb.ac.id
}

Received: November 2017

Accepted: September 2018

\begin{abstract}
:
Purpose: The purpose of this research is to develop an inter-organizational model of coordination in hinterland chain of hub-and-spoke in export trade logistics, where dryport works as a spoke and seaport as a hub.

Design/methodology/approach: The model defines a conceptual model that coordinates several actors involved in handling the flow of goods and the information (documents) for exporting goods via dryport, where their activities are interdependent. The first step of modelling investigated an existing business process of export system via dryport. The second step designed a conceptual model that simplified this business process by splitting it into stages: (1) identifying waste; (2) waste analysis; (3) benchmarking of logistics coordination in selected countries; and (4) streamlining the process. Several alternatives conceptual model of coordination are proposed, in which the development is based on inter-organizational system (IOS) approach. The model is then evaluated by experts to choose the best conceptual model of coordination that suits the real system, especially in Indonesia. The chosen model was then being validated by developing simulation using agent-based approach and discrete-event simulation.
\end{abstract}

Findings: The overaching findings of this research is coordination mechanism in logistics export process. There are two basic mechanisms in document preparation, three basic mechanisms in quarantine inspection, and three basic mechanisms in inland transportation and handling. These mechanisms were used to develop a conceptual model to improve the effectiveness of logistics export process. The coordination in proposed model used a central coordination hub (N:M or N:1:M).

Originality/value: The paper improves the inter-organizational system among involved actors for exporting goods via dryport (hub-and-spoke typology). Moreover, this paper improves hinterland coordination that considering flow of goods and information, which was rarely done by other researchers.

Keywords: coordination, hub-and-spoke, inter-organizational system, hinterland chain, logistics

\section{To cite this article:}

Sholihah, S.A., Samadhi, T.M.A.A., Cakravastia, A., \& Nur Bahagia, S. (2018). Coordination model in hinterland chain of hub-and-spoke export trade logistics. Journal of Industrial Engineering and Management, 11(4), 776-793. https://doi.org/10.3926/jiem.2538 


\section{Introduction}

In export trade logistics, there are two main activities: seaport activities on sea-side and hinterland activities on land-side. Hinterland activities start from contract between exporter/shipper and consignee abroad, until its container arrive in container yard of seaport on a specified due date. However, exporters have difficulties in fulfilling export contracts and closing time due-date in seaport, due to congestion on physical flow of goods and on processing the flow of information in the form of documents accompanying the physical flow.

In the physical flow of goods, severe congestion usually occurs both inside and outside the seaport, where trucks dominate the use of roadways. This hampers flow of goods at seaport area. Traffic congestion happens mainly because of the limited capacity of seaport. To overcome this phenomenon, a logistics facility as an extended gate of seaport is needed, where there are inland containers/custom depots (ICD), as well as logistics center which includes warehousing, transportation and other added-value services (Woxenius, Roso \& Lumsden, 2004). This type of logistics' facilities is well known as dryport. Here, a dryport is a place to consolidate and distribute goods, and also as an integrated and intermodal extension of seaport (Nam \& Song, 2011). Thus, export goods to be delivered will come from several points of origin (warehouses/manufactures), be consolidated at a spoke, then flowed to the hub (concept of hub-and-spoke). In maritime logistics context, this concept is known as hub-and-spoke - seaport as a hub of dryport (spoke). Hub-and-spoke network reduce the number of point-to-point direct loads that underutilized. As a result, it increasing load factors and reducing total operating costs (Lin \& Chen, 2004).

In flow of information/documents, exchange of information/documents involves several actors i.e.: business entities and government agencies, where interdependent activities occur between actors. If coordination among actors does not work well, it will affect the smoothness of export. Based on a survey of trade across nation conducted by World Bank (2013), the average export time in Indonesia is 17 days, in which document preparations process is $64,7 \%$ of export time. Idle time for containers waiting to be processed further shows low coordination among involved actors in planning and scheduling operations, ranging from drayage to line-haul operations (Ducruet \& Van Der Horst, 2009). Thus, it indicated that there is a problem of coordination in export trade.

\subsection{Hub-and-Spoke Logistics}

Council of Supply Chain Management Professionals defined logistics as "part of supply chain management that plans, implements and controls the efficient, effective forward and reverse flow and storage of goods, services and related information between the point of origin and the point of consumption in order to meet customer's requirement'. Based on the definition, logistics consist of all relevant activities in the process of flow of goods from point of origin to final destination point, including the activities of transportation, warehousing, purchasing, distribution, etc.

By definition, hub is a center of a circular object; a center of activities (Merriam-Webster Online Dictionary). In term of logistics, the concept of hub itself has some terminology related to its function as storage and transportation, for example logistics center, logistics zone, terminal of goods, distribution center, warehousing, intermodal terminal, etc. The development in logistics refines the definition of logistic center/hub. There are three perspective of logistics center/hub: traditional logistics and supply chain perspective, freight transport perspective, and international facility location perspective (Nam \& Song, 2011).

Meanwhile, concept of hub-and-spoke logistics can be described as shipments coming from several points of origin which are consolidated in the main terminal (e.g. hub) and transferred to each destination via radial link (e.g. spoke) (Nam \& Song, 2011). Based on this concept, the hub can be either a seaport (where dryport is the spoke) or a dryport (where industrial area is the spoke). If dryport turns out to be a spoke from a seaport, thus it is necessary to have an integrated intermodal connection from seaport. In activity of moving goods from inland to seaport (hinterland transportation), there are three modes that can be used to reach the dryport as an intermodal chain of ship (Korean Maritime Institute, 2005). Figure 1 illustrates the link between port and its hinterland based on mode of transportation. 


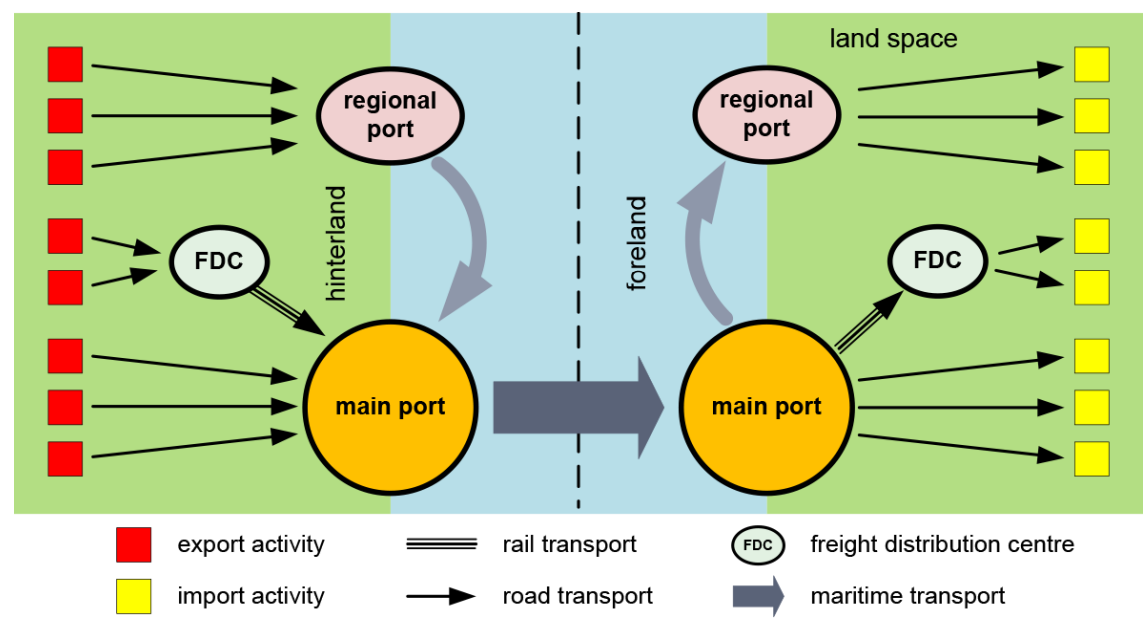

Figure 1. Hinterland transportation (Korea Maritime Institute, 2005)

As shown on Figure 1, there are a number of link to moving goods from and to ports. The transport modes can be trucks (road), rail, and barge. If goods are transported by road, then container will be directly transported to the port. If using rail mode, the containers first will be transported by truck to Freight Distribution Center (FDC) - drayage operation, then transported massively to the port by train. Similar to rail, by barge, the containers first will be transported by truck to regional port then transported massively to the port by barge. Due to the usual traffic congestion on road (Zahran, Bennett \& Smith, 2011, 2013), the combination of transportation modes should minimize the use of road transport (Zahran, Tan, Yap, Rahman \& Husaini, 2017; Voon, Kadir, Belayan, Poon \& Zahran, 2017).

\subsection{Concept of Coordination}

In maritime logistics, hinterland chain issues are about moving goods from inland to seaport or vice versa. In term of hub-and-spoke, hinterland chain is inland flow of good to a hub (seaport) through a spoke (dryport) or vice versa. Bottleneck in door-to-door chain occurs mostly in hinterland (Van Der Horst \& De Langen, 2008). This causes hinterland transport costs to be more expensive than maritime transport costs (De Langen \& Douma, 2010). Thus, hinterland access becomes more important since it determines competitive gain of seaport (Tongzon \& Heng, 2005). Many actors are involved in hinterland chain (Brooks et al. 2009) (where each actor tends to maximize their benefit) and the fact that hinterland transport cost is more expensive than maritime transport (De Langen \& Douma, 2010), makes the coordination in hinterland chain become important.

Coordination is found in multi-disciplines. Therefore, definition of coordination varies according to the context in which coordination occurs. American Heritage Dictionary defines coordination as the act of working together in harmony. In Inter-organizational System (IOS) area, Malone and Crowston (1990) defined coordination as the act in managing/organizing interdependency activities to achieve a goal. Based on these definitions, coordination components are: (1) the purpose; (2) some activity; (3) some actors; and (4) interdependence. Thus, theory of coordination is related to how the act can be coordinated, which means, how actors can work together in harmony by managing interdependencies among them.

If coordination is defined as managing dependencies, then it is necessary to characterize different types of dependencies and identify its coordination processes to manage it. Interdependence between activities can be analyzed in terms of "common object" that is involved in a certain way, i.e.: shared resources, producer/consumer relationship (e.g. prerequisite constraint, transfer, usage), and simultaneity constraint. The common object restricts how each activity perform the work. Different pattern in utilizing common object will produce different dependency types. Knowledge of interdependence in a situation could lead to alternative proposal of how to manage it (Malone \& Crowston, 1990).

In terms of communication and information system based on inter-enterprises technology, researchers in inter-organizational system (IOS) stated that managing interdependence is a main concept in understanding and 
formulating role of information technology (Kumar \& Van Dissel, 1996). By definition, IOS is an information system which connects one or more enterprises/organizations and facilitates the exchange of products and services (Bakos, 1991, in Lang, Moonen, Srour \& Zuidwijk, 2008). Area of IOS is broader than just the information exchange between actors in supply chain. Here, IOS has potential for deployment of information systems that support in collaboration of product development, process control, or other knowledge sharing.

Some researchers in IOS identified how organizations interact in term of managing their interdependent activities. Kumar and Van Dissel (1996) stated that there are three ways in which organizational units depend on each other, i.e. centralized dependency, sequential dependency, and reciprocal dependency. Centralized dependency happens when some units of the organization use and divide same resources. Sequential dependency happens when output of a unit become input of another unit. Reciprocal dependency happens when some units use input-output for their activity in which are result from back and forth interaction between them. In this typology, each unit receives input from one and produces output to the other, interactively.

Based on transactional backbone, Lang et al. (2008) stated that there are four types of architecture in connecting interorganizational activities:

\begin{tabular}{|c|c|}
\hline Type of Architecture & Descriptions \\
\hline Bilateral hub $(1: 1)$ & $\begin{array}{l}\text { - Point-to-point (P2P) relationship between two separate systems } \\
\text { - A direct relationship between two business partners } \\
\text { - The most basic form of relationship } \\
\text { - Works well for an important relationship } \\
\text { - Too expensive for connecting P2P two small business partners. }\end{array}$ \\
\hline Private hub $(1: \mathrm{N})$ & $\begin{array}{l}\text { - Hub structure which enable connected with partners } \\
\text { - Internal application only requires a single point of connection } \\
\text { - Standardized access for external partners } \\
\text { - Commonly initiated by the powerful party to connect with other small parties. }\end{array}$ \\
\hline $\begin{array}{l}\text { Central orchestration hub } \\
\mathrm{N}: \mathrm{M} \text { or } \mathrm{N}: 1: \mathrm{M})\end{array}$ & $\begin{array}{l}\text { - Like a private hub; but generally, run by independent operator } \\
\text { - Focus on supply chain orchestration } \\
\text { - Process focused } \\
\text { - Expected to work best in industries without dominant parties }\end{array}$ \\
\hline $\begin{array}{l}\text { Modular distributed plug \& } \\
\text { play architecture (N:M) }\end{array}$ & $\begin{array}{l}\text { - No permanent linkage - plug \& connect capabilities } \\
\text { - Parties connect when interaction needed, exchange information and conduct business } \\
\text { - Standardization very important } \\
\text { - Processes are leading mechanism }\end{array}$ \\
\hline
\end{tabular}

Table 1. Type of IOS Architecture

\subsection{Coordination in Hub-and-Spoke Export Trade Logistics}

The chain activities of hub-and-spoke maritime logistics is shown at Figure 2 below:

In logistics layer, generally the hub-and-spoke hierarchy network, which performs door-to-door chains, consist of: local services (drayage operations) and line-haul operations (Lin \& Chen, 2004). Flow of goods is always accompanied with flow of information (including documents) and flow of finances. The flow of information for exported goods involves several actors from business entities (transaction layer) and government agencies (government layer). Therefore, it can be seen that in hinterland chain of export through spoke involves several actors, in which each actor have their own roles and activities that are interdependent. Thus, the quality of hinterland access depends on the behavior of involved actors (Ducruet \& Van Der Horst, 2009). If coordination among actors does not work well then it will affect the smoothness of export. 


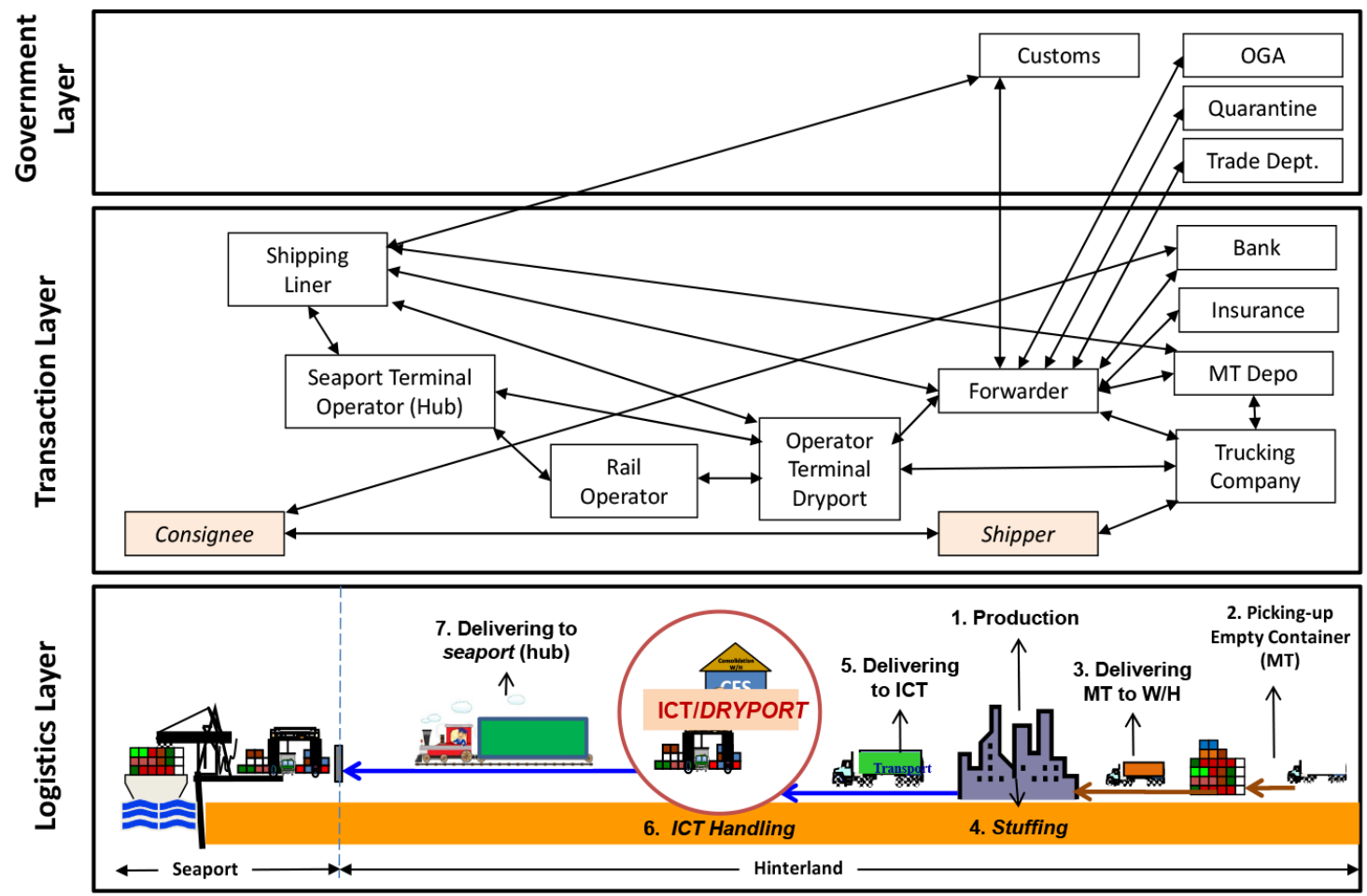

Figure 2. The Chain of Hub-and-Spoke Maritime Logistics

Coordination issues in hub-and-spoke of export are elaborated in Table 2. There are four coordination issue in which several actors in achieving common goals engage in interdependent activities, such as: shared resources, when some activities share limited resources; prerequisite, output of one activity required by the next activity; and simultaneity, where some activity must be performed at the same time.

\begin{tabular}{|c|c|c|c|}
\hline No. & Coordination Issue & Involved Actor & Interdependence \\
\hline 1. & $\begin{array}{l}\text { Discrepancy of schedule between readiness } \\
\text { of goods and its documents. }\end{array}$ & $\begin{array}{l}\text { Shipper, Forwarder, Customs, Trade and } \\
\text { Industry Dept., Shipping Line, etc. }\end{array}$ & $\begin{array}{l}\text { Shared resources and } \\
\text { prerequisite }\end{array}$ \\
\hline 2. & $\begin{array}{l}\text { Duration of issuing export documents } \\
\text { (i.e. export declaration, COO, etc.) }\end{array}$ & $\begin{array}{l}\text { Forwarder, Customs, Trade and Industry } \\
\text { Dept., Quarantine, and other government } \\
\text { agencies. }\end{array}$ & Prerequisites \\
\hline 3. & $\begin{array}{l}\text { The lack of conformity in arrival of empty } \\
\text { container and the completion of goods in } \\
\text { warehouse/factory. }\end{array}$ & $\begin{array}{l}\text { Shipper, forwarder, trucking company, } \\
\text { empty container depo. }\end{array}$ & $\begin{array}{l}\text { Simultaneity constraints } \\
\text { and shared resources }\end{array}$ \\
\hline 4. & $\begin{array}{l}\text { The lack of conformity of the container's } \\
\text { arrival schedule in spoke and the departure } \\
\text { to hub. }\end{array}$ & $\begin{array}{l}\text { Shipper, forwarder, trucking company, } \\
\text { inland terminal operator, rail company. }\end{array}$ & Simultaneity constraints \\
\hline
\end{tabular}

Table 2. Coordination Issues in Hub-and-Spoke of Export Trade

\subsection{Gap in Knowledge at Previous Studies}

Many studies have been addressing coordination problem in hinterland transportation (Van Der Horst \& De Langen, 2008), the conceptualization of coordination and cooperation strategies (Brooks, McCalla, Pallis \& Van Der Lugt, 2009), coordination on the hinterland chain of seaports with connections using rail mode (Woxenius et al. 2004; Van Der Horst \& Van Der Lugt, 2009) and Inter-organizational System (IOS) approach in coordination of port-based planning (Van Baalen, Zuidwijk \& Van Nunen, 2008). Research related to conformity of scheduling in maritime logistics include coordination in making truck-job-order on drayage operations considering empty containers (Vidovic, Radivojevic \& Rakovic, 2011; Zhang, Yun \& Moon, 2011) and some studies have begun to 
consider the time window (Caris \& Janssens, 2009; Braekers, Caris \& Janssens, 2011; Escudero, Munuzuri, Arango \& Onieva, 2011). Meanwhile, some studies on coordination of integrated schedule from drayage, spoke and hub operations are on freight logistics express shipping with modes on short-haul and long haul are trucks (Lin \& Chen, 2004), the flow of goods between the terminals on the intermodal trucks and train (Gambardella \& Rizolli, 2002) with considering arrival/departure of trains (time window) (Wang \& Yun, 2011) and considering enviromental issues - $\mathrm{CO}_{2}$ emissions (Sun, Hrušovský, Zhang \& Lang, 2018; Zahran, 2013; Said, Zahran \& Shams 2017), and intermodal multicommodity routing problem with scheduled services (IRM-S) using trucks and scheduled and capacitated maritime services (Ayar \& Yaman, 2012). However, previous studies have assumed that documents of good has been completed. In reality, the congestion occurs in the preparation of export documents. In terms of coordination, most are still sequential, one-direction of coordination and have not considered interaction between actors. Thus, in order to decrease time and cost of exporting goods, research question is how the coordination among involved actors in handling physical flow of goods and information (documents) can help arranging exported goods to meet the due exporting date (closing time).

This paper will propose a conceptual model of coordination-among-actors in handling the flow of goods and the information (documents) in exporting goods via inland container terminal/dryport. Chapter 2 explains existing business process exporting goods via inland container terminal/dryport. Chapter 3 design some alternatives conceptual model of coordination. Chapter 4 evaluate the propose alternatives models. Chapter 5 validation and explains results of proposed model, while Chapter 6 gives conclusion and further study.

\section{Existing Business Process}

Identification of existing export business process for agricultural or animal products in Indonesia has been conducted for container goods with FCL shipping unit. Generally, it can be divided into four groups of activities: documents preparation, custom clearance and inspection, inland transportation and handling, and port and terminal handling (World Bank, 2013). Export start when shipper/exporter makes a contract export with importer, preparing goods, contact a forwarding company to help preparing export documents and transporting goods on behalf of shipper until the container enter gate-in at hub terminal (spoke). These activities involve several actors, where each actor have their own roles and activities that interdependent. Interaction between actors can be seen in Figure 3.

In preparation of $\mathrm{B} 2 \mathrm{~B}$ documents, shipper submit the request of document directly to another actor. In preparation of $B 2 G$ documents, shipper delegates all the process to forwarder. On behalf o shipper, then forwarder submit the export documents to each government agency through online-based system. Although Indonesia has already Indonesia National Single Window (INSW), it has not fully implemented single submission. Each government agency has their own online-based system that has not been integrated with each other. It caused the duplication in data input and data archive. Moreover, it has not fully paperless system, in which users still need to submit physical documents at office hour. Similarly, in preparation of B2B documents, the exchange of document still a paper-based system.

In custom clearance and inspections (green color), physical and document inspections are performed in two government agencies: Quarantine and Customs, after forwarder submitted the request. Even though both agencies inspect the same document/data and same goods, but they have different focus. Quarantine focus on health of goods, meanwhile Customs focus on border clearance and tax. Process of Quarantine inspection carried out when all goods to be exported are ready. Inspection begin with document check in order to find out type of goods and destination country, so it can define a proper sample testing that meet requirement of destination country. Physical inspection is conducted using sample of product which then be tested in lab to find out whether goods need some treatments or not. If it need treatment, then first Quarantine will provide necessary treatment then release Phytosanitary/Veterinary Certificate. Meanwhile, custom inspection is conducted by screening document first then physical inspection. For non-priority, physical inspection is performed by monitoring stuffing goods to container. For container security, mostly it still use manual seal.

In inland transportation and handling (blue color), booking and scheduling are done by forwarder, manually. Here, forwarder book shipment to trucking operator for drayage operation by road, and to ICT operator for 
intermodality by rail. Here, ICT operator (as spoke) will coordinate with seaport operator (as hub) regarding schedule, which is linked to shipping liners' schedule on seaport. In tracking and tracing system of shipment, mostly it still using conventional system (by call truck driver) for updating its current location, therefore it's not flexible in shipment scheduling. Time-table of export system shows at Figure 4.

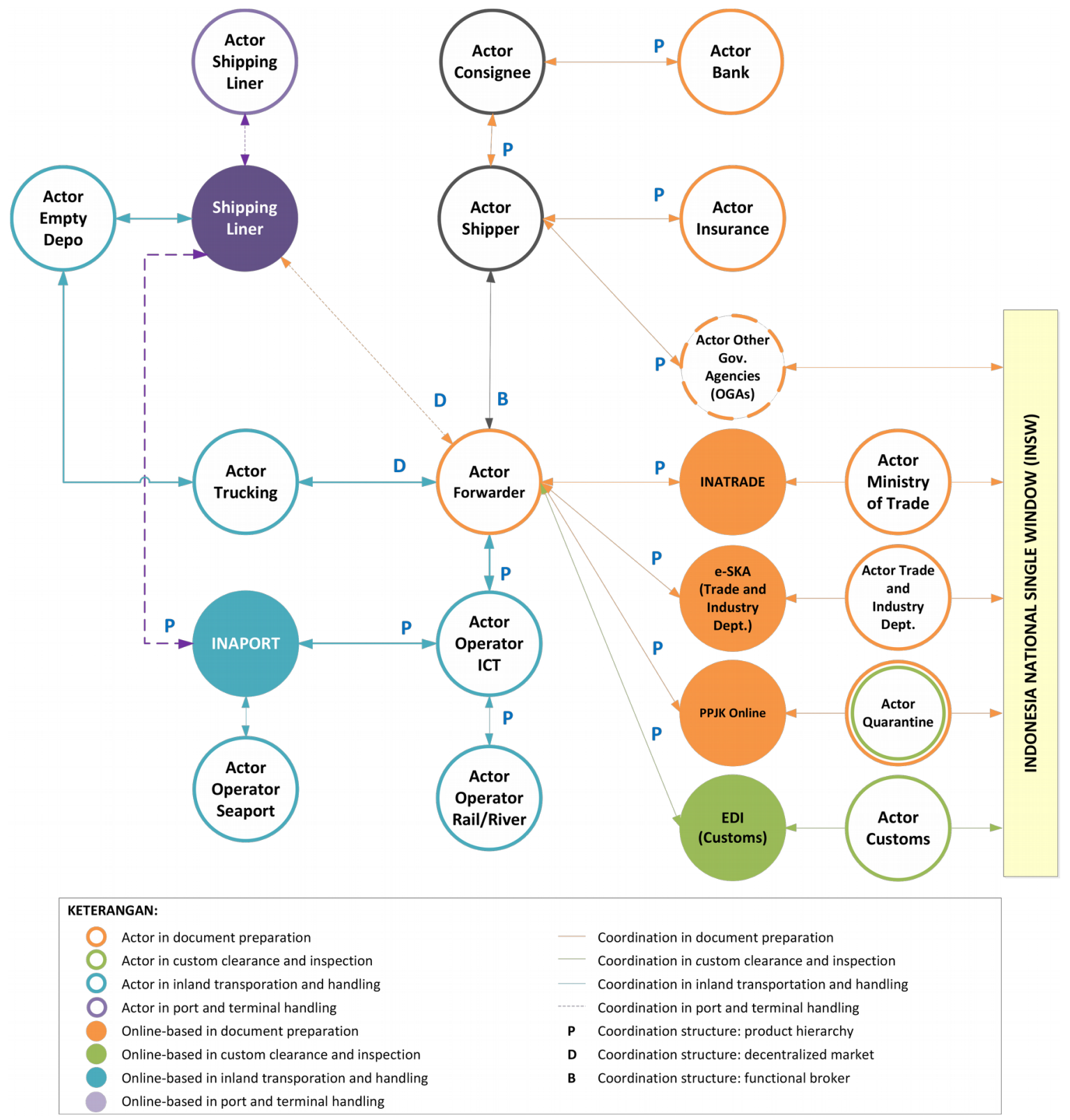

Figure 3. IOS Architecture of Existing System

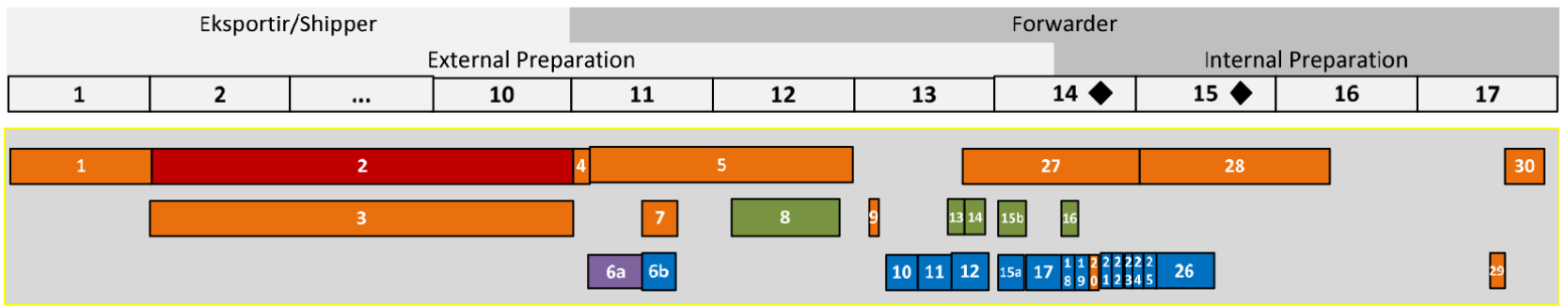

Figure 4. Time Table of Export (Existing) 
As shown at Figure 4, based on responsibility, process can be divided into two: under exporter/shipper and under forwarder. Meanwhile, based on place of preparation, process can be divided into external preparation and internal preparation. External preparation is a process that is performed outside the spoke (dryport), such as preparing documents and goods. Internal preparation is a process that is performed start when container entering gate-in of spoke. In existing process, almost all document preparations and custom clearance and inspections are carried out outside dryport (external preparation), which take 79.4\% of 17 days export time (World Bank, 2013), where goods arrive in dryport a few hours before closing time at dryport.

Based on identification of existing business process, coordination in scheduling flow of goods and information are still a series or type of interdependence is a prerequisite constraint. Prerequisite constraints interdependence is which activities in generating output must be completed before commencement other activity that uses its output (Malone \& Crowston, 1994). Interdependence of simultaneity constraint should occur when deciding delivery scheduling of goods from shipper to dryport. However, current coordination among shipper and forwarder is still done in one direction. Forwarder makes a decision, then shipper will follow this decision. Here, decision-making process made manually (did not use certain tools in decision making). Information sharing still manual and onedirection. The impact is information that goods could not meet the due-date in spoke is known in last minute and it raises penalty fees.

From existing coordination and referring to IOS architecture where forwarder interact with all actors involved, in can be concluded that existing coordination among actors in different unit of organizations is an orchestration central hub architecture. Forwarder as independent operator focus on managing supply chain and focus on process. The weakness of existing system is coordination still in one-direction, so synchronization is not run effectively.

\section{Designing a Conceptual Model}

To make an improvement of current condition, then waste in process of exporting goods are identified. The causes of waste are:

(1) Duplication of data input activity in issuing export documents in GA (Customs, Quarantine, and Ministry of Trade);

(2) Lead time in processing request of permit/document in GA, where mechanism of delivery/retrieval of physical documents is done per batch for effectiveness of work due to lack of human resources.

(3) In dryport operation occur shared resources of tools and operator who operate it. However, scheduling of resources still manual, so it lead to waiting time in queuing; and

(4) Unsynchronized scheduling in readiness of goods and its document to meet the due-date of train departure (drayage operation). For extreme case, if container arrived late and the next train or other alternative transport could not catch closing time in seaport (hub), then this will lead to huge penalty cost.

Referring to waste analysis, recommendations for improvement will be proposed for each cause of problems:

(1) Duplication of data input activity. Solution of shared resources in this case is the use of shared data information. It can be done in the presence of a database network. Moreover, standardized of data input needs to be applied, so information/data can be instantly used as an input in issuing other documents. It also minimizes error in data entry.

(2) Mechanism of delivery/retrieval of physical documents by forwarder. Solution of this problems is by submission of document electronically. Electronic data exchange system can save time and cost.

(3) Shared resources in dryport operation. Currently, all activities in dryport is not scheduled properly, except for the operation of lift-on lift-off containers from/to the train. Thus, assign tools or operator properly, it is necessary to coordinate the process with advance booking activity and notification from the tools/operators that is being used.

(4) Unsynchronized scheduling in readiness of goods at shipper and the departure of train (drayage operation). In this simultaneity constrains, coordination can be done by intensive communication (reciprocal) among actors, so synchronization occurs in scheduling. With this coordination, then "chaos" before closing time in spoke is expected no longer exist. 
Based on description above, then a conceptual model of coordination among actors in exporting goods via dryport were made. This conceptual model of coordination is based on benchmark inter-organizational (IOS) architecture in selected countries that have similarity of hinterland characteristics with Indonesia (archipelago) and lead in logistics performance: Singapore, Hong Kong - China, Netherlands and USA (Sholihah, Nur Bahagia, Cakravastia \& Samadhi, 2017). The purpose of benchmark study is to know how other countries perform the export process. Based on existing and benchmark of IOS architecture, Table 3 shows that generally each process or export has basics mechanisms.

In document preparation, there are two basic mechanisms: (1) decentralized, which is non-single window or unintegrated; and (2) centralized, which is fully-integrated. In custom clearance and inspections, there are three basic mechanisms for quarantine inspection: (1) both inspection and treatments of goods are performed by CIQ; (2) treatments are performed by licensed cooperator and CIQ will inspect and verify the treatment based on product sample; and (3) treatments are performed during production time by manufacturer and CIQ will inspect and verify the treatment based on sample of product and database Quality Check. Meanwhile, for inspection by Customs, there are two basic mechanism: (1) manual; and (2) electronic, using x-Ray scanning. In inland transportation and handling, there are three basic mechanisms: (1) decentralized in which all activities are conducted by various actors; and (2) semi-decentralized in which several actors collaborate in services.

\begin{tabular}{|c|c|c|c|}
\hline Process & Mechanism-1 (Existing) & Mechanism-2 & Mechanism-3 \\
\hline $\begin{array}{l}\text { Document } \\
\text { Preparation }\end{array}$ & $\begin{array}{l}\text { Decentralized } \\
\text { - Single window (partly and not } \\
\text { fully integrated) } \\
\text { - Non-single submission } \\
\text { - e-Doc (partly) }\end{array}$ & $\begin{array}{l}\text { Centralized (Singapore, } \\
\text { Singapore, Hong Kong, } \\
\text { Netherlands, USA) } \\
\text { - Single window } \\
\text { - Single submission } \\
\text { - e-Doc } \\
\text { - e-Certificate, transfer G2G } \\
\text { - Tracking ' } n \text { tracing of process }\end{array}$ & \\
\hline \multicolumn{4}{|c|}{ Custom Clearance and Inspection } \\
\hline$\square$ Quarantine & $\begin{array}{l}\text { Both inspection and treatments } \\
\text { of goods are performed by } \\
\text { Quarantine }\end{array}$ & $\begin{array}{l}\text { (Netherlands) } \\
\text { - Treatments are performed } \\
\text { during production time by } \\
\text { manufacturer, and inspection } \\
\text { based on database Quality } \\
\text { Check (QC). }\end{array}$ & $\begin{array}{l}\text { (USA) } \\
\text { - Treatment are performed by } \\
\text { licensed cooperator. }\end{array}$ \\
\hline$\square$ Customs & $\begin{array}{l}\text { - First document inspection, then } \\
\text { physical inspection (if needed). } \\
\text { - Manual inspection } \\
\text { - Manual seal (mostly) }\end{array}$ & $\begin{array}{l}\text { (Singapore, Hong Kong, } \\
\text { Netherlands, USA) } \\
\text { - Physical and document } \\
\text { inspection are done } \\
\text { simultaneously. } \\
\text { - CIQ document is used as } \\
\text { verification. } \\
\text { - X-Ray; e-Seal }\end{array}$ & \\
\hline $\begin{array}{l}\text { Inland } \\
\text { Transportation } \\
\text { and Terminal }\end{array}$ & $\begin{array}{l}\text { Decentralized } \\
\text { - Many actors } \\
\text { - Manual information sharing } \\
\text { - } \text { Booking and arrangement of } \\
\text { shipment are done manually by } \\
\text { Forwarder } \\
\text { - Manual tracking and tracing of } \\
\text { goods } \\
\text { - Gate-in inspection: manual }\end{array}$ & $\begin{array}{l}\text { Decentralized (Singapore, Hong } \\
\text { Kong) } \\
\text { - Many actors } \\
\text { - Electronic information } \\
\text { sharing. } \\
\text { - Pre-notification on arrival in } \\
\text { terminal } \\
\text { - Gate-in inspection: } \\
\text { compatibility of physical } \\
\text { goods and its document (x- } \\
\text { Ray and document scanning). }\end{array}$ & $\begin{array}{l}\text { Semi-Decentralized } \\
\text { (Netherlands, USA) } \\
\text { - Many actors, several actors } \\
\text { collaborate. } \\
\text { - Electronic information } \\
\text { sharing. } \\
\text { - Pre-notification on arrival in } \\
\text { terminal } \\
\text { - Gate-in inspection: } \\
\text { compatibility of physical } \\
\text { goods and its document (x- } \\
\text { Ray and document scanning). }\end{array}$ \\
\hline
\end{tabular}

Table 3. Existing and Benchmark of Inter-Organizational Architecture 
To improve performance of existing system, then basic mechanisms can be generated as many as 36 possibilities of alternative models. All possible alternative models are then analyzed on the basis of conformity with the existing system, suggested improvement from waste analysis and performance criteria, i.e. export time. Then, feasible solution is obtained with performance criteria that give better processing time:

- Document preparation: centralized (mechanism-2)

- Quarantine: inspection based on database quality check (mechanism-2) and treatment by licensed cooperator (mechanism-3)

- Customs: simultaneous process of inspection and using x-Ray and e-Seal (mechanism-2)

- Inland transportation and handling: decentralized (mechanism-2) and semi-decentralized (mechanism-3)

Based on feasible solutions, then alternative solutions are as describes at Table 4.

\begin{tabular}{|c|c|c|c|c|}
\hline Process & Alternative-1 & Alternative-2 & Alternative-3 & Alternative-4 \\
\hline Document preparation & mechanism-2 & mechanism-2 & mechanism-2 & mechanism-2 \\
\hline Quarantine & mechanism-2 & mechanism-3 & mechanism-2 & mechanism-3 \\
\hline Customs & mechanism-2 & mechanism-2 & mechanism-2 & mechanism-2 \\
\hline Inland transportation and handling & mechanism-2 & mechanism-2 & mechanism-3 & mechanism-3 \\
\hline
\end{tabular}

Table 4. Alternative Models

\section{Model Evaluation}

Evaluation of alternative models was conducted based on assessment of influencing factors in selection of the best conceptual model of coordination that suits the real system (especially in Indonesia). Since the alternative models has not been implemented, then expert judgment method was done in which potential performance of the model was measured by expert in maritime logistics, especially in export system via hub-and-spoke network.

Generally, logistics system performance can be measured by output, outcome and impact of system. Output is a factual data that is objective, measurable and the impact can be perceived directly. Outcome is a subjective information that obtained from impression of experience in interacting with the system. Impact are a long-term impact gained by society. Here, performance evaluation was only based on outcome and impact, because output can only be obtained in real system. In addition, evaluation related to implementation was also included. Therefor, performance of outcome, impact and implementation are dimensions in evaluation. Each dimension consist of elements, where each element consist of indicators that derived into question items in questionnaire.

Outcome of inter-organizational coordination system of export in hub-and-spoke can be seen in terms of port performance (UNCTAD, 1976), multimodal process (Marlow \& Casaca, 2003), and logistics performance (World Bank, 2014; Bayhaqi \& Yuhua, 2013). The impact can be derived from national logistics competency (Marlow \& Casaca, 2003; World Bank, 2014) and potential economic impact, competitiveness (Bayhaqi \& Yuhua, 2013). In addition, evaluation related to implementation can be seen in terms of easiness and implementation cost that consist of total cost of system's ownership, partnership opportunity cost, responsiveness of market (McLaren, Head \& Yuan, 2002) and willingness to change of actors involved. Evaluation structure of dimension-indicatorelement shows at Table 5 .

Data collection was done based on expert judgment in logistics maritime. Evaluation tool is a questionnaire that derived from indicators of evaluation structure (see Table 5) with evaluation from 0 to 10, where 10 indicates excellent performance. Profile of respondents on data collection was forwarder $(50 \%)$, regulator $(33 \%)$, operator of inland transport $(8 \%)$ and exporters association $(9 \%)$. The result of data collection shows at Table 6.

In order to select the best alternative model, then paired-test was conducted to see whether expert's judgment was statistically different. Based on tests of normality Kolmogorov-Smirnov and Shapiro Wilk (see Table 7), the data of models are not all normally distributed. 
Here paired-test used is a non-parametric rank sum test Wilcoxon Signed Rank Test with hypothesis:

$$
\begin{array}{ll}
H_{0}: & D_{1} \text { and } D_{2} \text { are identical } \\
H_{1}: & \text { 1) } D_{1} \text { is shifted left of } D_{2} \text { (positive ranks) } \\
& \text { 2) } D_{1} \text { is shifted right of } D_{2} \text { (negative ranks) }
\end{array}
$$

\begin{tabular}{|c|c|c|}
\hline Dimension & Element & Indicator \\
\hline \multirow[b]{5}{*}{ Outcome } & Throughput & - Throughput (C1) \\
\hline & Logistics cost & - Logistics Cost of Export (E1) \\
\hline & Timeliness & - Pick up/delivery shipment within scheduled or expected delivery time (C2) \\
\hline & Seamless Connectivity & $\begin{array}{l}\text { - Time performance (C4) } \\
\text { - Reliability of transit time/transport availability on multimodal process (C3) }\end{array}$ \\
\hline & Coordination & $\begin{array}{l}\text { - Scheduling arrangement on synchronization of flow of good and flow of } \\
\text { document. (B1) } \\
\text { - Ease and Affordability of Arranging International Shipments. (B2) } \\
\text { - Information sharing inter-organizational. (B3) } \\
\text { - Accuracy of information and data regarding status of shipment } \\
\text { (documentation). (B4) } \\
\text { - Tracking and tracing of process. (B5) } \\
\text { - Tracking and tracing of goods. (B6) }\end{array}$ \\
\hline \multirow{2}{*}{ Impact } & Competitiveness & - Impact on national competitiveness. (D1) \\
\hline & Logistics Competency & - Impact on national logistics competency. (D2) \\
\hline \multirow{4}{*}{ Implementation } & $\begin{array}{l}\text { Easiness of } \\
\text { implementation }\end{array}$ & $\begin{array}{l}\text { - Overall system (A1) } \\
\text { - Document preparations (A2) } \\
\text { - Custom clearance and inspections (A3, A4) } \\
\text { - Inland transportation and handling (A5) }\end{array}$ \\
\hline & $\begin{array}{l}\text { Ownership cost of } \\
\text { system }\end{array}$ & $\begin{array}{l}\text { - Cost of system implementation (F1) } \\
\text { - Cost of coordination process (F2) } \\
\text { - Cost of integration process (F3) } \\
\text { - Cost of data translation and integration (F4) }\end{array}$ \\
\hline & $\begin{array}{l}\text { Partnership } \\
\text { opportunity cost }\end{array}$ & $\begin{array}{l}\text { - Partnership instability cost (F5) } \\
\text { - Switching cost (F6) }\end{array}$ \\
\hline & Willingness to change & - Change of authority. (G1) \\
\hline
\end{tabular}

The result of statistical paired-test Wilcoxon Signed Rank Test can be seen in Table 8.

Table 5. Evaluation Structure

\begin{tabular}{|r|r|r|r|r|r|}
\hline Var. & Existing & Alt-1 & \multicolumn{1}{c|}{ Alt-2 } & \multicolumn{1}{c|}{ Alt-3 } & \multicolumn{1}{c|}{ Alt-4 } \\
\hline A1 & 5.45 & 6.00 & 6.67 & 6.75 & 7.08 \\
\hline A2 & 4.83 & 7.32 & 7.32 & 7.32 & 7.32 \\
\hline A3 & 5.38 & 6.78 & 7.44 & 6.56 & 7.22 \\
\hline A4 & 6.00 & 8.07 & 8.07 & 8.07 & 8.07 \\
\hline A5 & 4.50 & 6.70 & 6.70 & 6.70 & 6.70 \\
\hline B1 & 4.68 & 6.33 & 6.71 & 6.83 & 6.96 \\
\hline B2 & 4.88 & 6.67 & 6.79 & 6.92 & 6.96 \\
\hline B3 & 3.96 & 6.71 & 6.88 & 6.96 & 6.83 \\
\hline B4 & 4.38 & 6.83 & 6.79 & 7.08 & 6.96 \\
\hline B5 & 4.25 & 7.08 & 7.21 & 7.00 & 7.17 \\
\hline D1 & 4.08 & 6.92 & 7.08 & 6.83 & 6.92 \\
\hline
\end{tabular}

\begin{tabular}{|c|r|r|r|r|r|}
\hline Var. & Existing & \multicolumn{1}{|c|}{ Alt-1 } & \multicolumn{1}{c|}{ Alt-2 } & Alt-3 & Alt-4 \\
\hline B6 & 3.92 & 6.83 & 7.02 & 7.13 & 7.02 \\
\hline C1 & 4.79 & 6.92 & 6.92 & 7.00 & 7.04 \\
\hline C2 & 4.92 & 7.25 & 7.33 & 7.50 & 7.42 \\
\hline C3 & 4.25 & 7.00 & 7.17 & 7.04 & 7.08 \\
\hline C4a & 5.00 & 7.25 & 7.63 & 7.25 & 7.63 \\
\hline C4b & 5.86 & 7.57 & 7.57 & 7.57 & 7.57 \\
\hline C4c & 5.88 & 7.06 & 7.06 & 7.06 & 7.06 \\
\hline C4d & 4.67 & 7.67 & 7.67 & 7.67 & 7.67 \\
\hline C4e & 5.86 & 7.67 & 7.67 & 7.83 & 7.83 \\
\hline C4f & 4.10 & 6.10 & 6.10 & 6.00 & 6.00 \\
\hline F1e & 4.30 & 6.70 & 6.70 & 6.90 & 6.90 \\
\hline
\end{tabular}




\begin{tabular}{|c|r|r|r|r|r|}
\hline Var. & Existing & Alt-1 & \multicolumn{1}{|c|}{ Alt-2 } & \multicolumn{1}{c|}{ Alt-3 } & \multicolumn{1}{c|}{ Alt-4 } \\
\hline D2 & 4.42 & 7.08 & 7.17 & 7.00 & 7.25 \\
\hline E1 & 3.42 & 6.58 & 6.83 & 6.75 & 6.75 \\
\hline F1a & 4.83 & 6.17 & 6.33 & 6.08 & 6.21 \\
\hline F1b & 4.92 & 7.17 & 7.17 & 7.17 & 7.17 \\
\hline F1c & 5.13 & 6.86 & 7.43 & 6.88 & 7.38 \\
\hline F1d & 5.43 & 7.43 & 7.43 & 7.43 & 7.43 \\
\hline F1e & 3.70 & 6.50 & 6.50 & 6.40 & 6.40 \\
\hline F2a & 4.42 & 6.50 & 6.79 & 6.67 & 6.63 \\
\hline F2b & 4.83 & 7.17 & 7.17 & 7.17 & 7.17 \\
\hline F2c & 5.50 & 7.06 & 7.38 & 7.19 & 7.50 \\
\hline F2d & 5.21 & 6.71 & 6.71 & 6.71 & 6.71 \\
\hline F2e & 3.60 & 6.40 & 6.40 & 6.40 & 6.40 \\
\hline F1a & 4.75 & 6.58 & 6.71 & 6.58 & 6.63 \\
\hline F1b & 4.50 & 7.33 & 7.33 & 7.18 & 7.33 \\
\hline F1c & 5.38 & 6.88 & 7.13 & 6.88 & 7.13 \\
\hline F1d & 5.50 & 6.57 & 6.57 & 6.57 & 6.57 \\
\hline
\end{tabular}

\begin{tabular}{|c|r|r|r|r|r|}
\hline Var. & Existing & \multicolumn{1}{|c|}{ Alt-1 } & \multicolumn{1}{|c|}{ Alt-2 } & \multicolumn{1}{c|}{ Alt-3 } & \multicolumn{1}{c|}{ Alt-4 } \\
\hline F4a & 5.00 & 6.42 & 6.83 & 6.50 & 6.46 \\
\hline F4b & 4.67 & 7.04 & 7.04 & 7.04 & 7.04 \\
\hline F4c & 5.38 & 7.63 & 7.88 & 7.63 & 7.88 \\
\hline F4d & 5.21 & 6.79 & 6.79 & 6.79 & 6.79 \\
\hline F4e & 4.20 & 6.50 & 6.60 & 6.30 & 6.40 \\
\hline F5a & 5.33 & 5.75 & 6.21 & 6.33 & 6.54 \\
\hline F5b & 5.33 & 6.00 & 6.00 & 6.00 & 6.00 \\
\hline F5c & 5.38 & 6.50 & 6.75 & 6.50 & 6.75 \\
\hline F5d & 5.00 & 5.86 & 5.86 & 5.86 & 5.86 \\
\hline F5e & 5.10 & 5.50 & 5.50 & 6.10 & 6.10 \\
\hline F6a & 3.92 & 6.29 & 6.42 & 6.29 & 6.25 \\
\hline F6b & 4.33 & 6.92 & 6.92 & 6.92 & 6.92 \\
\hline F6c & 4.75 & 6.88 & 7.00 & 6.88 & 7.00 \\
\hline F6d & 4.71 & 6.71 & 6.71 & 6.71 & 6.71 \\
\hline F6e & 3.70 & 6.30 & 6.30 & 6.30 & 6.30 \\
\hline G1 & 9.25 & 9.08 & 9.08 & 8.67 & 8.67 \\
\hline
\end{tabular}

Table 6. Result of Data Collection

\begin{tabular}{|l|r|r|r|r|r|r|}
\hline \multirow{2}{*}{} & \multicolumn{4}{|c|}{ Kolmoonov-Smirnov ${ }^{\mathrm{a}}$} & \multicolumn{3}{c|}{ Shapiro-Wilk } \\
\cline { 2 - 7 } & Statistic & \multicolumn{1}{|c|}{ df } & \multicolumn{1}{c|}{ Sig. } & Statistic & \multicolumn{1}{c|}{ df } & \multicolumn{1}{c|}{ Sig. } \\
\hline Existing & 0.140 & 54 & $0.010^{*}$ & 0.824 & 54 & 0.000 \\
\hline Alt-1 & 0.093 & 54 & $0.200^{*}$ & 0.953 & 54 & 0.035 \\
\hline Alt-2 & 0.092 & 54 & $0200^{*}$ & 0.960 & 54 & 0.072 \\
\hline Alt-3 & 0.101 & 54 & $0.200^{*}$ & 0.967 & 54 & 0.138 \\
\hline Alt-4 & 0.074 & 54 & $0.200^{*}$ & 0.982 & 54 & 0.597 \\
\hline
\end{tabular}

a. Lilliefors Significance Correction

Table 7. Test of Normality

\begin{tabular}{|c|c|c|c|c|}
\hline & \multicolumn{3}{|c|}{ Wilcoxon Signed Rank Test } & \multirow{2}{*}{ Remarks } \\
\hline & $\mathbf{Z}$ & Asymp. Sig. (2-tailed) & Remarks & \\
\hline Alt-1 - Existing & -6.385 & 0.000 & Negative ranks & Alt-1 > Existing \\
\hline Alt-2 - Existing & -6.385 & 0.000 & Negative ranks & Alt-2 > Existing \\
\hline Alt-3 - Existing & -6.385 & 0.000 & Negative ranks & Alt-3 $>$ Existing \\
\hline Alt-4 - Existing & -6.385 & 0.000 & Negative ranks & Alt-4 > Existing \\
\hline Alt-2 - Alt-1 & -4.522 & 0.000 & Negative ranks & Alt-2 > Alt-1 \\
\hline Alt-3 - Alt-1 & -2.040 & 0.041 & Negative ranks & Alt-3 > Alt-1 \\
\hline Alt-4 - Alt-1 & -4.059 & 0.000 & Negative ranks & Alt-4 > Alt-1 \\
\hline Alt-3 - Alt-2 & -2.421 & 0.015 & Positive ranks & Alt-3 $<$ Alt-2 \\
\hline Alt-4 - Alt-2 & -0.057 & 0.955 & Negative ranks & Alt $-4=$ Alt -2 \\
\hline Alt-4 - Alt-3 & -3.216 & 0.001 & Negative ranks & Alt-4 > Alt-3 \\
\hline
\end{tabular}

Table 8. Paired-Test Wilcoxon Signed Rank Test

As seen on Table 8, results of paired-test show that there are differences in distribution of models, except Alternative-2 and Alternative-4 have the same value distribution, in which Existing < Alternative- $1<$ Alternative-3 $<$ Alternative 2 = Alternative-4. These results indicate that Alternative- 2 and Alternative- 4 are the most suitable 
implemented model in Indonesia (with significance level 5\%), where both models provide equally good performance. IOS architecture of Alternative- 2 and Alternative- 4 can be seen in Figure 5.

Generally, coordination in both selected models are central coordination hub (N:M or N:1:M), where forwarder play as a conductor/product manager. Here, i-DAGANG as a platform to submit document and application, has a role as hub structure that allow to connect with partners. Internal application (government agencies, terminal operator and transport operator) only requires a single connection (i-DAGANG) and standardized access for external partners (shipper/exporter/forwarder). This type of pattern helps in managing interdependencies, because information sharing between government agencies and other stakeholders reduce the number of linkage and focus on supply chain orchestration.

In document preparation (orange color), duplication in data input and data archive are solved by single connection and single submission mechanism via i-DAGANG. Online-based application manage shared resources interdependencies, where in conventional, users need to submit physical documents at office hour while they have limited employee. Moreover, user can predict process time and monitor whether the request is accepted or rejected (with notification) using tracing and tracking of process, so user can get response faster (within an hour). It helps in scheduling process in order to manage prerequisites and simultaneity constraints.

In custom clearance and inspections (green color), Custom's inspection mostly using x-Ray scanning and e-seal system. Meanwhile for quarantine inspection using mechanism where treatments are performed during production time by manufacturer and CIQ will inspect and verify the treatment based on sample of product and database Quality Check. This mechanism is carried out to change sequence of process, in order to manage prerequisites interdependencies. However, there are requirement to implement this mechanism: exporter have to be proactive to search import requirement in destination country and QC database is open access for client.

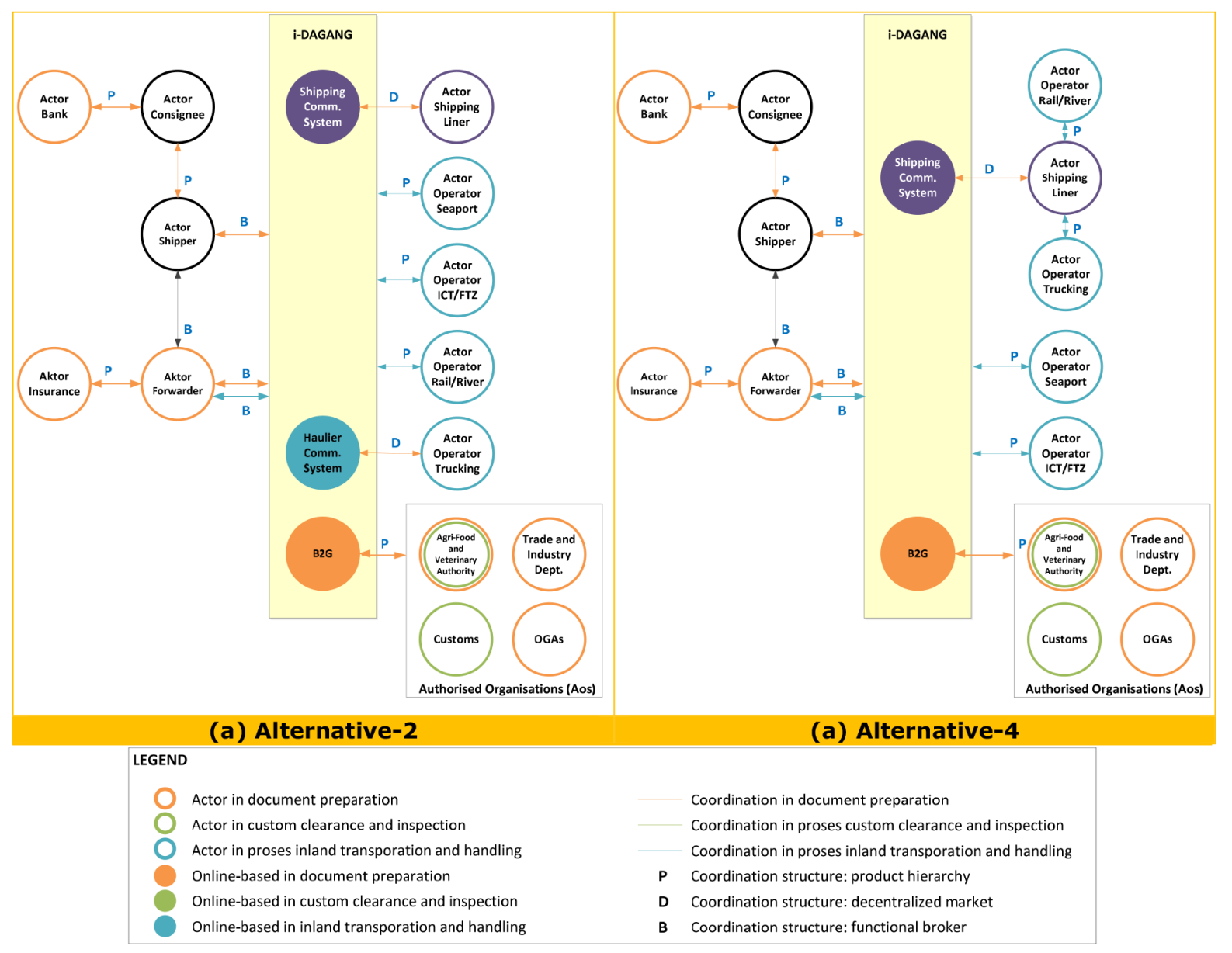

Figure 5. IOS Architecture of Best Alternative Model 
In inland transportation and handling (blue color), Alternative-2 using decentralized mechanism where forwarder/shipper contact each transport operator and arrange the shipment through modules in i-DAGANG, Shipping Community System and Haulier Community System (HCS). Shipping Community System is a module in i-DAGANG in which all activities involving shipping liner, port, etc. can be done through this module. While HCS serve haulier community (trucking's), in which all activities involving drayage freight services can be done through this module. HCS consist of trucking companies who collaborate in managing inland transport activity (drayage). All trucking companies act as if they are a single company under the HCS, where truck assignment is done through HCS. HCS system includes tracking and tracing (TnT) system and pre-notification of arrival in ICT and seaport that is applied very strictly. Thus, it can reduce driver time in terminal. Meanwhile, inspection of compatibility between goods and its documents is carried out during Gate-In inspection in ICT or seaport, where physical inspection is conducted using X-Ray.

Alternative-4 using semi-decentralized mechanism where some actors are collaborated. Booking to Shipping Liner or Ocean Carriers is performed via Shipping Community System in i-DAGANG. Then Shipping Liner will coordinate the goods shipment from warehouse/manufacturer to terminal, in this case Ocean Carriers make collaboration with drayage and railway transport companies. However, this collaboration of actor can lead to vertical integration, where it will affect cost of services whether it become cheaper or more expensive, depending on behavior of the lead actor on collaboration. Here also applied pre-notification of arrival at terminal, which is a provision for receiving container via rail. Container without pre-notification will be rejected or will be examined further.

\section{Validation and Discussion}

Validation of model will simulate model to examine whether the selected model have better performance than existing model. However, in Alternative-4 the model performance depends on some actors have behavior in vertical integration, which need further exploration on these behaviors. So, this validation will only examine performance of Alternative-2.

Simulation design of coordination in export accommodate flow of information and flow of goods. Agent-based modelling $(A B M)$ is used to simulate flow of information, because $A B M$ suitable to illustrate interaction of interdependencies among agents/actors (Baldwin, Sauser \& Cloutier, 2015; Irannezhad, Hickman \& Prato, 2017). Meanwhile, flow of goods used discrete-events simulation (DES) which is used at an operational/tactical level (Tako \& Robinson, 2012) and models the operation of a system a discrete sequence of events in time (Sharma, 2015).

The case study focuses on exporting goods from industrial area which exported through spoke TPKB Gedebage (Dryport) in Bandung and its hub is Port of Tanjung Priok in Jakarta, Indonesia. The dataset was provided from current condition (demand, transport time, schedule, etc.) and regulation and expert judgments (expected performance of Alternative- 2 for each proses). On steady state condition with level of confidence 95\%, the principal measures of performance and the results are shown in Table 9.

The comparison between model performance validates that proposed model have better performance than existing model. The analysis of the results reveals that mean of export time of proposed model is 4.8 days with standard deviation 0.5 day, which decrease $24.6 \%$ from existing. Meanwhile, number of containers fail to meet the closing time is $0.08 \%$. In this case, time for document preparations have significantly decrease rather than other process.

\begin{tabular}{|l|r|r|r|r|r|r|r|r|}
\hline \multirow{2}{*}{ Proses } & \multicolumn{2}{|c|}{ Proposed Model (Alternative-2) } & \multicolumn{4}{c|}{ Existing Model } \\
\cline { 2 - 10 } & \multicolumn{1}{|c}{ Mean } & \multicolumn{1}{|c|}{ Min } & \multicolumn{1}{c|}{ Max } & St Dev. & Mean & \multicolumn{1}{c|}{ Min } & Max & St Dev. \\
\hline Export (days) & 4.8 & 3.3 & 6.8 & 0.6 & 6.4 & 4.8 & 9.0 & 0.6 \\
\hline Document preparation (days) & 4.8 & 3.3 & 6.8 & 0.6 & 6.3 & 4.8 & 8.9 & 0.6 \\
\hline Customs clearance and inspections (hours) & 2.6 & 0.6 & 5.8 & 1.1 & 29.4 & 15.2 & 44.5 & 5.7 \\
\hline Inland transportation and handling (days) & 1.8 & 1.0 & 3.3 & 0.5 & 2.8 & 2.0 & 4.4 & 0.5 \\
\hline
\end{tabular}

Table 9. Result of Simulation 
In document preparations, the average time is 4.8 days, which is almost the same as overall export times because the documents/informations initiate and go side by side with flow of goods. Some significant difference between the proposed model and the existing model are in export shipping orders and preparation of B2G documents. It shows that proposed model of coordination can manage prerequisites dependencies, especially for B2G documents with high requirements and high level of accuracy between documents.

In customs clearance and inspections, the average time is 2.6 hours. A significant difference between the proposed model and the existing model is in quarantine inspection. The implementation of treatments carried out simultaneously during production time is able to reduce quarantine inspection time.

In inland transportation and handling, the average time is 1.8 days. A significant difference between the proposed model and the existing model is in time for booking sea and land transport because shipping planning and scheduling are faster due to the availability of mode of transport and booking process become real time. Meanwhile, shipping time is relatively the same because both proposed and existing models are assumed to use the same travel route, so for speed and distance for both models are relatively the same. Likewise, stuffing schedules that follow factory/warehouse operating time and train schedule, both models used the existing conditions.

However, challenge in implementation of such a system is not easy. Transition from conventional to online-based system is done gradually over the years. To ensure system can run smoothly, general requirements needed in implementation are:

- System in each actor involved must be integrated with single window system.

- Standardization of document format

- Reliability of network security

- System for checking authenticity of documents

- Collaboration with destination countries and connecting our single window system to ensure they can receive electronic documents (e-Doc/e-Cert).

- Reliability of database management system

- In tracking and tracing, all process and result should be recorded and reported in real time.

\section{Conclusion and Further Study}

Exporters have difficulties in fulfilling export contracts and closing time due-date in seaport, due to congestion on physical flow of goods and on processing the flow of information in the form of documents accompanying the physical flow. In the physical flow of goods, severe congestion occurs frequently both inside and outside the seaport. This hampers flow of goods at seaport area. Congestion happens mainly because of the limited capacity of seaport. To overcome this phenomenon, a logistics facility as an extended gate of seaport is needed. This type of logistics facilities is well known as dryport. In maritime logistics context, this concept is known as hub-and-spoke - seaport as a hub of dryport (spoke). In flow of information/documents, several actors involved both from business entities and government agencies (GA). These actors have their own roles and activities that interdependent, where interdependent activities occur between actors.

This paper designed four alternatives of conceptual model of coordination-among-actors in handling the flow of goods and information (documents) at exporting goods via inland container terminal/dryport, study case in Indonesia. These alternative models built from coordination mechanisms. There are two basic mechanisms in document preparation, three basic mechanisms in quarantine inspection, and three basic mechanisms in inland transportation and handling.Two most suitable alternative models of coordination were chosen: Alternative- 2 and Alternative-4. Generally, coordination in the two selected models is a central coordination hub (N:M or N:1:M), where forwarder play as a conductor/product manager. i-DAGANG as a platform to submit document and application, had a role as the hub structure that allowed to connect with partners. Internal application (government agencies, terminal operator and transport operator) only required a single connection (i-DAGANG) and standardized access to external partners (shipper/exporter/forwarder). This type of pattern helped in managing 
interdependencies, because information sharing between government agencies and other stakeholders reduced the number of linkages and focused on supply chain orchestration.

The limitations of this study are: the shipping unit is Full Container Load (FCL) which is less complex in terms of process and behavior of actors than Less-Than-Container Load (LCL). Additionally, the developed model has not considered the behavior of each actor in the case vertical integration, and has not considered resolution of conflicts between actors. The developed simulation model has not considered comprehensive risk analysis in the event of failure or breakdown in an online-based system. So further research is needed to cover these limitations.

\section{Declaration of Conflicting Interests}

The authors declared no potential conflicts of interest with respect to the research, authorship, and/or publication of this article.

\section{Funding}

The authors received no financial support for the research, authorship, and/or publication of this article.

\section{References}

Ayar, B., \& Yaman, H. (2012). An Intermodal Multicommodity Routing Problem with Scheduled Services. Computational Optimization and Applications, 53(1), 131-153. https://doi.org/10.1007/s10589-011-9409-z

Baldwin, W.C., Sauser, B., \& Cloutier, R. (2015). Simulation Approaches for System of Systems: Events-Based versus Agent Based Modeling. Procedia Computer Science, 44, 363-372. https://doi.org/10.1016/j.procs.2015.03.032

Bayhaqi, \& Yuhua (2013). Improving Connectivity in the Asia Pasific Region - Perspectives of the APEC Policy Support Unit. Singapore: Asia-Pacific Economic Cooperation. Available at: http://publications.apec.org/Publications/2013/10/Improving-Connectivity-in-the-Asia-Pacific-Region (Accessed: May $\left.10^{\text {th }}, 2016\right)$.

Braekers, K., Caris, A., \& Janssens, G.K. (2011). A deterministic annealing algorithm for a bi-objective full truckload vehicle routing problem in drayage operations. Procedia Social and Behavioral Sciences, 20, 344-353. https://doi.org/10.1016/j.sbspro.2011.08.040

Brooks, M., McCalla, R., Pallis, A., \& Van Der Lugt, L.M. (2009). Coordination in strategic port management: the case of Atlantic Canada's ports. Proceeding of International Association of Maritime Economists.

Caris, A., \& Janssens, G.K. (2009). A local search heuristic for the pre-and end-haulage of intermodal container terminals. Computers \& Operations Research, 36, 2763-2772. https://doi.org/10.1016/j.cor.2008.12.007

De Langen, P.W., \& Douma, A. (2010). Challenges for using ICT to improve coordination in hinterland chains: An overview.. International Journal of Transport Economics, 37(3), 287-304.

Ducruet, C., \& Van Der Horst, M. (2009). Transport integration at european ports: measuring the role and position of intermediaries. EJTIR, 9(2), 121-142.

Escudero, A., Munuzuri, J., Arango, C., \& Onieva, L. (2011). A satellite navigation system to improve the management of intermodal drayage. Advanced Engineering Informatics, 25, 427-434.

https://doi.org/10.1016/j.aei.2011.02.005

Gambardella, L.M., \& Rizolli, A.E. (2002). Agent-based planning and simulation of combined rail/road transport. Simulation, 78(5), 293-303. https://doi.org/10.1177/0037549702078005551

Irannezhad, E., Hickman, M., \& Prato, C.G. (2017). Modeling the Efficiency of a Port Community System as an Agent-based Process. Procedia Computer Science, 109C, 917-922. https://doi.org/10.1016/j.procs.2017.05.422

Korea Maritime Institute (2005). Free Trade Zone and Port Hinterland Development. New York: United Nations ESCAP.

Kumar, K., \& Van Dissel, H.G. (1996). Sustainable collaboration: Managing conflict cooperation in interorganizational systems. MIS Quarterly, 279. 
Lang, N., Moonen, H.M., Srour, F.J., \& Zuidwijk, R.A. (2008). Multi agent systems in logistics: a literature and state- of-the-art review. ERIM Report Series, Reference No. ERS-2008-043-LIS. Rotterdam: Erasmus Research Institute of Management.

Lin, C.C., \& Chen, S.H. (2004). The hierarchical network design problem for time-definite express common carriers. Transportation Research Part B, 271-283. https://doi.org/10.1016/S0191-2615(03)00013-4

McLaren, T., Head, M., \& Yuan, Y. (2002). Supply chain collaboration alternatives: Understanding the expected costs and benefits. Internet Research, 12(4), 348-364. https://doi.org/10.1108/10662240210438416

Malone, T.W., \& Crowston, K. (1990). What is coordination theory and how can it belp design cooperative work systems. Proceedings of the Conference on Computer Supported Cooperative Work. Los Angeles.

https://doi.org/10.1145/99332.99367

Malone, T.W., \& Crowston, K. (1994). The interdisciplinary study of coordination. Computing Surveys, 26(1), 87-119. https://doi.org/10.1145/174666.174668

Marlow, P.B., \& Casaca, A.C.P. (2003). Measuring lean ports performance. International Journal of Transport Management, 1, 189-202.

Nam, H.S., \& Song, D.W. (2011). Defining maritime logistics hub and its implication for container port. Maritime Policy \& Management, 38(3), 269-292. https://doi.org/10.1080/03088839.2011.572705

Said, S.N.B.M., Zahran, E.S.M.M., \& Shams, S. (2017). Forest Fire Risk Assessment Using Hotspot Analysis in GIS. The Open Civil Engineering Journal, 11, 786-801. https://doi.org/10.2174/1874149501711010786

Sharma, P. (2015). Discrete-Event Simulation. International Journal of Scientific \& Technology Research, 4(04), $136-140$.

Sholihah, S.A., Nur Bahagia, S., Cakravastia, A., \& Samadhi, T.M.A.A. (2017). Benchmarking inter-organizational system architecture of trade facilitation in Singapore, Hong Kong, Netherlands and USA. International Journal of Trade, Economics and Finance, 8(6), 263-269. https://doi.org/10.18178/ijtef.2017.8.6.576

Sun, Y., Hrušovský, M., Zhang, C., \& Lang, M. (2018). A Time-Dependent Fuzzy Programming Approach for the Green Multimodal Routing Problem with Rail Service Capacity Uncertainty and Road Traffic Congestion. Complexity, 2018. https://doi.org/10.1155/2018/8645793

Tako, A.A., \& Robinson, S. (2012). The application of discrete event simulation and system dynamics in the logistics and supply chain context. Decision Support Systems, 52(4), 802-815.

Tongzon, J., \& Heng, W. (2005). Port privatization, efficiency and competitiveness: Some empirical evidence from container ports (terminals). Transportation Research Part A, 39, 405-424.

UNCTAD (1976). Port Performance Indicators. Available at: https://unctad.org/en/PublicationsLibrary/tdbc4d131sup1rev1 en.pdf (Accessed: May $7^{\text {th }}, 2016$ ).

Van Baalen, P., Zuidwijk, R., \& Van Nunen, J. (2008). Port Inter-Organizational Information Systems: Capabilities to Service Global Supply Chain. In Van Baalen, P., Zuidwijk, R., \& Van Nunen, J., Technology, Information and Operations Management, 2(2-3), 81-241. https:// doi.org/10.1561/0200000008

Van Der Horst, M., \& De Langen, P. (2008). Coordination in hinterland transport chains: a major challenge for the seaport community. Maritime Economics \& Logistics, 10, 108-129. https:/ / doi.org/10.1057/palgrave.mel.9100194

Van Der Horst, M., \& Van Der Lugt, L. (2009). Coordination in railway hinterland chains: an institutional analysis. Proceedings of LAME 2009 (International Association of Maritime Economists).

Vidovic, M., Radivojevic, G., \& Rakovic, B. (2011). Vehicle routing in containers pickup up and delivery processes. Procedia Social and Behavioral Sciences, 20, 335-343. https://doi.org/10.1016/j.sbspro.2011.08.039

Voon, N.H., Kadir, S.N.H.A., Belayan, M.A., Poon, S.H., \& Zahran, E.S.M.M. (2017). Rides for Rewards (R4R): A Mobile Application to Sustain an Incentive Scheme for Public Bus Transport. In Computational Intelligence in Information Systems, 60-71. https://doi.org/10.1007/978-3-319-48517-1_6

Wang, W.F., \& Yun, W.F. (2011). Scheduling for inland container truck and train transportation. Internationa Journal of Production Economics, 143(2), 349-356. https://doi.org/10.1016/j.ijpe.2011.10.016 
World Bank (2013). Ease of Doing Business in Indonesia - Trading Across Border. Available at: http://www.doingbusiness.org/data/exploreeconomies/indonesia/\#trading-across-borders (Accessed: January 2013).

World Bank (2014). Connecting to Compete 2014: Trade Logistics in the Global Economy-The Logistics Performance Index and Its Indicators. Available at: https://openknowledge.worldbank.org/discover?query=logistics \%20 (Accessed: May $7^{\text {th }}, 2016$ ).

performance $\% 20$ index.

Woxenius, J., Roso, V., \& Lumsden, K. (2004). The dry port concept - connecting seaports with their binterland by rail. Proceeding of ICLSP (305-319). Dalian.

Zahran, E.M.M. (2013). A Novel Approach to Improve the Air Quality Predictions of Air Pollution Dispersion Modelling systems. International Journal of Environmental Research, 7(1), 205-218. https://doi.org/10.22059/ijer.2012.599

Zahran, E.S.M.M., Bennett, L.D., \& Smith, M.J. (2011). A GIS-based approach to automating the collection of geospatial road network data. Traffic, Engineering \& Control Global Research Hub, 52 (7), 295(5).

Zahran, E.S.M.M., Bennett, L.D., \& Smith, M.J. (2013). 3D Visualization of Traffic-Induced Air Pollution Impacts of Urban Transport Schemes. Journal of Computing in Civil Engineering, 27(5), 452-465. https://doi.org/10.1061/(ASCE)CP.1943-5487.0000198

Zahran, E.S.M.M., Tan, S.J., Yap, Y.H., Rahman, E.K.A., \& Husaini, N.H. (2017). A novel approach for identification and ranking of road traffic accident hotspots. MATEC Web of Conferences. https://doi.org/10.1051/matecconf/201712404003

Zhang, R., Yun, W.Y., \& Moon, I.K. (2011). Modeling and optimization of a container drayage problem with resource constraints. International Journal of Production Economics, 133, 351-359.

https://doi.org/10.1016/j.ijpe.2010.02.005

Journal of Industrial Engineering and Management, 2018 (www.jiem.org)

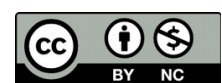

Article's contents are provided on an Attribution-Non Commercial 4.0 Creative commons International License. Readers are allowed to copy, distribute and communicate article's contents, provided the author's and Journal of Industrial Engineering and Management's names are included. It must not be used for commercial purposes. To see the complete license contents, please visit https://creativecommons.org/licenses/by-nc/4.0/. 